\title{
Editorial: Reimagining Science and Technology Education in the COVID-19 Portal
}

\section{STEVE ALSOP ${ }^{*}$ AND LARRY BENCZE ${ }^{¥}$}

*Faculty of Education and Department of Science and Technology Studies, York University, Toronto, Canada; salsop@yorku.ca

${ }^{¥}$ OISE, University of Toronto; larry.bencze@utoronto.ca

\section{Responses}

JASTE is a non-refereed, open-access, journal. We encourage reader feedback on contributions to it. Please send your comments, suggestions, etc. about this paper to either or both Steve Alsop and Larry Bencze. Thanks!

\section{Introduction}

The impact of the COVID-19 pandemic has been swift and savage. So many of us have watched press briefings and news reports as realities unfold and fatality figures rise. This week, the numbers of total confirmed cases approach 10 million and the global deaths are around 500 thousand. Yesterday (June $24^{\text {th }}$ ) was one of the largest increases in these figures. What was once a pandemic predominately of rich countries, is now affecting the Global poor. Privileged, wealthy countries have struggled, and are still struggling, with wanting medical infrastructure, absences of basic personal protective equipment (PPE) and testing apparatus. Many frontline care workers, doctors and nurses, have died because of shortages of disposable, basic health kits. The vulnerable, homeless, hungry, sick and elderly have been hard hit. So have Black and Asian people, which some statistics suggest are up to 50\% more likely to die from COVID19. Too many now mourn the loss of family, friends, colleagues and acquaintances. People are struggling to get-by with fiscal insecurities and economic hardships that as White, cis-gender privileged academics we struggle to even imagine. Lockdown is probably the largest standardized policy the world has ever known. It has contained the virus, saved millions of lives, but in so doing it has increased stress, anxieties and trauma. There has been a marked rise in domestic violence and mental illness.

Handwashing, lockdown and social distancing all make assumptions. Over the past few years, I (Alsop) have been working with students and teachers in the Dadaab refugee camps (Kenya) in a higher education initiative (BHER) ${ }^{1}$. As the pandemic was unfolding, I spoke with students and they reminded me of the luxury of soap, which many refugee families simply cannot afford (even those working on refugee teacher wages), let alone facemasks. They brought my attention to the impracticalities of social distancing in one of the largest refugee camps in the world, housing over 250 thousand people living in makeshift temporary accommodation for decades. In the camps, 20-30 families share a single water stand and line-up daily for declining food rations. They are deeply concerned about coronavirus, alongside chikungunya, malaria and cholera, all treatable diseases that still take many lives in the camps. I am reminded that there are now

\footnotetext{
${ }^{1}$ Borderless Higher Education for Refugees. Further details are available: https://www.bher.org/
} 
more refugees and displaced people in the world than ever before, and these figures will likely rise as a result of the pandemic.

The brutal murder of George Floyd by Minneapolis police is another world shaking event. This sickening and needless death and many others have led to uprisings in the US by Black Lives Matter (BLM) and those held in solidarity around the world. Protestors, in defiance of lock-down, have brought deeply ingrained injustices home. BLM have reignited and reoriented civil rights movements, bringing attention to racialized injustices, violence and police brutalities. The BLM movement has ruptured civic spheres and injustices that were somehow accepted as a tragic part of everyday life, are now repugnant and indefensible. As JASTE editors and authors, we stand in solidarity with BLM and all those who have taken to the streets in protest. We reflect on ways that science and education practices, including our practices, are deeply implicated in perpetuating anti-Black racism and inequalities. We acknowledge that racism is a public health and environmental issue that is further worsened by the COVID-19 pandemic.

We are all vulnerable to COVID-19 although, in practice, of course, the virus affects different groups in very different ways. The pandemic builds on ingrained inequalities and injustices of racism, colonialism, capitalism, class-struggle, poverty, food and health insecurities and environmental degradations. It is a crisis that builds on crisis. The following articles in this journal issue make this abundantly clear.

The planetary environmental crisis has been somewhat occluded by COVID-19. Buried in the media and news items are conflicting reports of nature flourishing with fauna and flora returning to cities, improving air quality, and greenhouse gas emissions still rising but doing so at reduced rates. Recent news items have marked the last 10 years as the hottest on record, and Siberia is currently grappling with debilitating temperatures and forest fires previously unknown. Indeed, some have asked whether the pandemic should be conceived as dry run - a warm-up act for something much worse. Others have seen it as a moment in which a Green New Deal might be realised.

Around the world, there has been mass closure of institutions of education to restrict the spread of the virus, millions of learners are now out-of-school. UNESCO has been monitoring school closures, highlighting how girls and rural, working class communities have been disproportionately affected. During the pandemic, makeshift educational arrangements have been put in place, mostly in the form of online and distance learning. Students and families lacking computers and stable WIFI connections are further marginalised. In the countries first affected, schools are now reopening. Education administrators, teachers and students are juggling (im)practicalities of social distancing, daily temperature testing, and how best to organise and timetable smaller classes. Teachers are managing unprecedented back-to-school anxieties and uncertainties. This virus is placing a hidden toll on young people and families. Many youth are reluctant to return. Lots have refused.

During lockdown, teachers and administrators have been offering students support and encouragment. We have been worrying about our students and how they are reacting to the circumstances, reaching out and offering compassion and care, sharing anxieties, and working together to make sure that assignments are completed, and courses finalised. We are continuously reminded that emotions and relationships form the basis of every successful classroom. Institutions of education provide support and infrastructures extending way beyond the academic curriculum. These institutions build communities, forge relationship, adding to community resilience and offering hope. Families and students rely on access to school meals, electronic communications and other material resources that schools provide. At York University, for example, over 800 students are reliant on the university food bank. It is important to remember that in lockdown these resources are largely unavailable. 
Teachers and students have been working together, supporting each other, sharing anxieties and feelings; listening to each other's stories. Teacher unions, teacher organisations and community groups are working together, mobilizing for change, reaching out to vulnerable communities — LGBTQ2 communities, working class communities, poor communities, black communities, communities of colour and indigenous communities - those often-hardest hit. They have been asking how we might best respond with mutual aid and support. Teachers have real expertise here. They understand and know how to listen to students and have histories of working with communities. This ground-level knowhow is notably absent from high-level government briefings. We are left wondering how centralised policies might have benefited from listening more intently to teachers' and students' local expertise, their networks and mobilisations. We are also keeping a close eye on governmental bailout and the extent to which they go to those in need, rather than the already wealthy and privileged.

The general point is that this pandemic is deeply conflicting and paradoxical. It is terrifying and disturbing and, yet, also potentially liberating. It has exposed the sutures of humanity and ripped these wide-open. COVID-19 makes visible what previously is cast to the shadows, muffled by the cotton wool of privilege and natural orders. Access to science and technology, whether in medical treatments or in classrooms has too often favoured those with particular cultural and economic capital. But, COVID-19 offers opportunities to re-educate, to reflect on what is important, and what needs to change; how can we listen more closely and join in solidarity with others and act. BLM guiding principles and accompanying resources, for example, offer radical bases for re-imagining schools, science and technology education, building on principles of: 1) Restorative justice, 2) Empathy, 3) Loving Engagement, 4) Diversity, 5) Globalism, 6) Queer Affirming 7) Trans Affirming, 8) Collective Value, 9) Intergenerational, 10) Black Families, 11) Black Villages, 12) Unapologetically Black, 13) Black Women (BLM, 2020).

What is undeniable is that, in this pandemic, the profound importance of science and technology education has been in plain sight. Few should now question the need for public engagement in science and technology and the ability to distinguish misinformation and political posturing (including, injecting UV light and disinfectant) from reliable scientific expertise. Viral epidemiology has not been a particularly prominent feature in many school science and technology curriculum. The fallacy of this absence has now been underscored. Many of us have had crash courses on R-numbers, logarithmic growth, and flattening curves, vaccine development, antibodies and herd-immunities, mechanisms of transmission, and the potency of soap and alcohol-based hand-sanitizers. Indeed, there has been a rise in scientific discussion, alongside those family members and friends who espouse proficiencies (sometimes a little too much) in epidemiology, virology, anti-bodies and vaccinations. There has been extended media coverage of scientific methods, the processes of developing and testing vaccination and the painstaking details and timescales entailed. Although we sense a media preference for university scientists solving complex problems, rather than commercialised, for-profit corporations seeking business opportunities and increased shareholder returns.

The point is that scientific knowledge that was once distant and largely invisible, perhaps even too hastily dismissed as irrelevant and esoteric, is now inescapable. Few can now legitimately refute, for example, that science and politics are deeply entwined, constitutive, and inseparable. This is a coproduction thesis that so many of us have been arguing (for many years) that should be part of the school curriculum. And many caregivers and parents who have been teaching with much creativity, reliance and fortitude, have re-kindled respect for the considerable expertise and skills of professional teachers. This seems a perfect opportunity to revisit and reform science curricula in schools and universities. 
This is not a time for metaphors of conflict, revolution and war (although these have emerged in some political rhetoric). In contrast, we are inspired and energised by Arundahati Roy's invitation to think about the pandemic as "a portal". This metaphor serves to vividly capture the loss of the present, ways in which radical ruptures leave us spinning, oscillating between the past and the present, seeking to make sense of remnants of that which has been lost alongside desires for change. Arundahati Roy (2020, para. 43) captures this all so beautifully:

Whatever it is, coronavirus has made the mighty kneel and brought the world to a halt like nothing else could. Our minds are racing back and forth, longing for a return to "normality", trying to stitch our future to our past and refusing to acknowledge the rupture. But the rupture exists, and in the midst of this terrible despair, it offers us a chance to rethink the doomsday machine we have built for ourselves. For many, nothing could be worse than a return to normal.

The point is that, as teachers and researchers, we can become cocreators in change. If social sciences teach us anything, it is that the future is not predetermined. To return to normal is simple not enough. In walking through the portal, we need to ask ourselves: what is now more visible and how might we appropriately respond? How can we walk with power and resolve, with vision and resilience, joining others including our students, and coming together in progressive alliances for necessary radical changes? It is time to consider what is important in [science and technology] education: what is relevant for people's lives and for planetary wellbeing and survival.

In the following articles you will sense a necessary hesitancy and fluidity of uncertainty, but this accompanies an inspiring and far-reaching progressiveness. Perhaps in this liminal moment, our science and technology education imaginations can break free from reductionist traditions, from market fetishisms, privatisation and high-stakes testing. We should ask ourselves what we need to hold onto and what should we let go. In the portal, Arundahati Roy (2020, last paragraph) invites travelling with light luggage:

We can choose to walk through it, dragging the carcasses of our prejudice and hatred, our avarice, our data banks and dead ideas, our dead rivers and smoky skies behind us. Or we can walk though lightly, with little luggage, ready to imagine an other world. And ready to fight for it.

We would like to thank all the authors involved in this special issue of JASTE. The COVID-19 educational portal is fluid and uncertain. It is destabilizing and demoralising. We respect and thank you for joining with us in this journey, for walking together. We respect your courage and commitments to shape responses, which are frozen in time at particular moment of publication. We acknowledge that most of the articles in this issue were finalised before the murder of George Floyd and therefore pay less attention to this world-changing event than might have been expected.

In assembling this issue, we were sensitive to the pressures of COVID-19 and not adding to already stressful workloads. This issue was not generated by a general call for submissions. The idea was to gather a group of authors as a first stage, offering provocations for what we truly hope are ongoing conversations. We encourage reactions and responses, whether large or small. JASTE is a open-access journal and we include authors contact details on all the submissions.

This issue comprises five articles. In what follows, the authors grapple with how to walk in the portal. Their thoughts and recommendations are truly inspiring and generative. We bring this editorial to a close with brief overviews. Needless to say, the articles far exceed these summaries and, as editors, we encourage you to read the full articles.

[1] Justin Dillon and Lucy Avraamidou - Toward a Viable Response to COVID-19 from the Science Education Community - offer delightfully direct system-wide observations and recommendations. They leave the science and technology education community with a single question: what can be done, and 
what can be done differently? A "social justice informed approach," they conclude with a vision for post-pandemic science education based upon recognising and challenging entrenched inequalities. They lament on the invisibility of science education, asking: where is the leadership from scholarship and scholarly professional organisations — such as AERA, EASE, ESERA, NARST and others?

Dillon and Avraamidou frame their response to COVID-19 in the form of seven questions. They reject reductionist curriculum tendencies, exacerbated by PISA, which are simply unable to offer the necessarily guidance and leadership in response to contemporary social and ecological imbalances and injustices. Instead, they propose that the science education community should purposefully reorientate curricula toward science, environment and health perspectives. They question whether science education research is situated within contemporary socio-political realities and bemoan ways that research still fixates on deficit models of pre-service teachers' understandings. They invite reflections on the importance of an affective turn in science education, associated with culturally sustainable pedagogies and pedagogies of care.

[2] Ajay Sharma - Phronetic Science for Wicked Times - courageously challenges a series of dualistic modernist assumptions and frames COVID-19 as a wicked problem for scientists and policy makers alike. Sharma invites considering COVID-19 as a "dualism-busting assemblage of the Capitalocene", arguing that traditional science and science education are simply not set up to overcome challenges like COVID-19. In response, he advocates abandoning "substantive ontology" and embracing a "posthuman relational ontology", which prioritises relations over entities and breaks free from commodification for profit. Sharma advocates transdisciplinary approaches to science, including sustainability science and phronetic science. Phronetic science draws on Aristotelian distinctions between episteme, techne and phronesis. The latter denoting practical wisdom and concretely situated judgements

In concluding, Sharma proposes two ways forward. First, he encourages joining with others, sharing and shaping critiques of hegemonic neoliberalism (including ecological modernization and green governmentality). Second, he turns to schools as suitable places to start transforming science, in part because of their emphasis on modernistic dualistic assumptions, but also because they can make a difference. He outlines a pedagogical approach that involves children repeatedly facing ethically fraught situations, experiencing gaps between knowledge and ethically informed actions, while mobilising with others and taking actions. Recent reforms in science and technology education (STSE and SSI) offer a firm starting point for this approach, although these have tended to overlook necessary ethical literacy.

[3] Lyn Carter - What's in a Name: Post-liberalism, COVID-19 and Science (Education) — insightfully deconstructs controversies over the SARS-CoV-2 name and associated forms of disinformation. Her detailed, eloquent scholarly analysis provides insight into "contiguous nature of science and politics" characterised by persistent attacks on the WHO and other controversies surrounding the coronavirus. Carter asks: why are health and scientific organisations being simultaneously valorised and vilified? As we grapple with containing the virus and move forward, this is a fundamental question for science education to consider, especially given its role in educating scientists and medical professionals. A more detailed political discussion of the geopolitical landscape makes this more intelligible. Carter overviews western political positions of liberalism, neoliberalism and post-liberalism and subsequent 
rise of right-wing populism (RWP). RWP is evident in recent attacks on leading health and scientific organisations, in which professional technical expertise no longer commands the respect that it once had under liberalism but is now conceived as "service providers akin to any other in market economy". Trump and other selected political leaders act to systemically undermine regulatory science through disinformation, serving as master 'bewilderers' within uncertain, fluid political contexts; risk "Twilight Zones" and Gramscian-type interreganums, in which "the old is dying and the new has yet to be born" (Gramsci).

In concluding, Carter turns to science education offering a series of curriculum possibilities including relevant scientific and technological knowledge and socially acute questions (SAQ) for pedagogical explorations. In response to RWP distain for science, she advocates for a science education that not only recognises the provisional nature of science but embraces the sociopolitical construction of science. It is no longer tenable to present science as apolitical. Perhaps what is most important of all is the development of resilience, in which actors are secure and confident in technical expertise and can produce risk mitigating actions.

[4] Larry Bencze - Post-pandemic Science \& Technology Education: An Opportune and Necessary Ideological Battle - firmly situates the pandemic within the crises of capitalism and the struggles for eco-socialist, more just and equitable worlds. These possibilities, he persuasively argues, necessitate radical, paradigmatic shifts in subjectivities and relational meanings and ideological redistributions. Bencze frames the SARS-CoV-2 virus as an 'instructional packet' with propagative capacities that enables commonalities to be drawn between the virus and capitalists. Central to Bencze's analyses is education's potential role in challenging false consciousness (framed as pro-capitalist dispositifs), through raising critical awareness (conscientização) leading to actions confronting and overcoming hegemonic influences of commodity and value production.

In a progressive and far-reaching analysis, Bencze outlines a particular pedagogical approach to science and technology education, STEPWISE, that builds on apprenticeship design and altruistic values. Bencze recognises the need for honesty about how people are situated but grasps the possibilities of using and redirecting cultural capital for altruistic changes. The educational model is structured in three stages: students reflect, teacher teaches and students practice. Central to this model are student-led 'research-informed and negotiated action (RiNA) projects. Bencze concludes by reflecting on pedagogical changes, in proposed and actualised forms. He recognises the challenges ahead, but draws inspiration from the teachers and students involved in STEPWISE and recent shifts in research and scholarship, including the upcoming 2021 annual AERA conference, which invites attendees to reject "apolitical stances that limit how our scholarship affects societies".

[5] Emma McKay — Luddism, Isolation and Education — reflects on technology and the pandemic. As a self-identified Neo-Luddite, McKay urges resisting technology at a time at which it seems to have become the substrate of our agencies and sociality. At a time of seclusion and contemplation, McKay advocates a "little methodological Luddism", in the form of critical attention to the idolatry and mythologization of high-tech and the associated extractive industry. Technology should be understood as a situated and goal orientated tool, judged against core ethical values of purpose, community and conviviality: "what is essential", "what can we do without?" "How can we get there together". This self-reflexive approach necessitates a deep re-examination and intimacy, made possible by releasing 
dependenance of techonology and associated values and joining and creating things together communally. To build a long and lasting world for all involves recognising how dependent we are on each other and the planet and to "go more slowly". This embraces local collectives, growing community resilience and collectively demanding change.

[6] Steve Alsop and Darren Hoeg - Collegial Conversations at a Time of COVID-19 — offer a response in the form of collegial conversations - a dialogue of letters. In a series of 4 exchanges (8 letters) over a period of two months as the pandemic unfolds, they discuss changing contexts and ways in which science and technology education might respond. Conversations start by lamenting the academic impulse to frame answers in the form of a COVID-generation, or COVID-society, or COVID education. Instead, they ask: as professional science and technology educators and researchers, what questions might we need now to find our feet again? The emerging exchanges seek to capture the fluidity of collegial conversations as different questions and perspectives emerge. They invite reflection on how to approach and explore ideas in dialogue, ways in which professional conversations stimulate thought and action. Such exchanges are being restricted through lockdown and artificial nature of working online.

Alsop and Hoeg reflect on their White, patriarchal academic privileges, recognising ways in which the pandemic impacts different groups in very different ways. They share teachable moments and curriculum approaches, questioning liberal models of science and technology education and citizenship that offer limited attention to social justice. They respond to the George Floyd killing and the subsequent uprisings and demonstrations in support, and in solidarity with, the BLM movement. As the conversations progress, they attach increasing importance to teachers, students and communities collaboratively fashioning educational responses focusing on, and responding to, injustices related to the global and local differential realities of the pandemic.

\section{References}

Black Lives Matter (2020). Black Lives Matter at School. Available at: https://blacklivesmatteratschool.com/

Roy, A. (2020). 'The pandemic is a portal'. Financial Times, April $3^{\text {rd }}$. Available at: https://www.ft.com/content/10d8f5e8-74eb-11ea-95fe-fcd274e920ca 